\title{
Development of high-affinity agonist- and antagonist radioligands for the GLP-2 receptor - powerful tools for the study of GLP-2 pharmacology
}

Sarina Gadgaard ${ }^{1}$, Wijnand van der Velden ${ }^{2}$, Sine Schiellerup ${ }^{2}$, Jenna Hunt ${ }^{2}$, Maria Gabe ${ }^{2}$, Johanne Windeløv ${ }^{2}$, Geke Boer ${ }^{2}$, Hannelouise Kissow ${ }^{2}$, Cathrine Ørskov² ${ }^{2}$ Jens Holst $^{2}$, Bolette Hartmann ${ }^{2}$, and Mette Rosenkilde ${ }^{3}$

${ }^{1}$ University of Copenhagen Faculty of Health and Medical Sciences

${ }^{2}$ University of Copenhagen

${ }^{3}$ University of Copenhagen

August 23, 2020

\begin{abstract}
Background: Glucagon-like peptide-2 (GLP-2) is a 33 amino acid pro-glucagon-derived hormone produced in the intestinal enteroendocrine L-cells with trophic actions on both the gut and bones. GLP-2(1-33) is cleaved by the ubiquitous protease dipeptidyl peptidase-4 (DPP-4), resulting in GLP-2(3-33) with competitive antagonistic properties on the GLP-2 receptor (GLP$2 \mathrm{R}$ ). Here we present two new hGLP-2 radioligands with different pharmacodynamic profiles. Experimental Approach: The methionine in position 10 of GLP-2(1-33) was substituted with tyrosine to enable oxidative iodination with incorporation of the iodine isotope [125I]. Similar substitution was done in GLP-2(3-33), thereby creating two new radioligands; an agonist [125]hGLP-2(1-33,M10Y) and an antagonist [125]-hGLP-2(3-33,M10Y). Both were characterized regarding competition binding, binding kinetics and target tissue autoradiography. Key results: High and similar binding affinities for the human GLP2R were observed for [125I]-hGLP-2(1-33,M10Y) and [125I]-hGLP-2(3-33,M10Y) with KD values of $59.3 \mathrm{nM}$ and $40.6 \mathrm{nM}$, respectively. The M10Y substitution did not change the functional properties of GLP-2(1-33) or GLP-2(3-33). The antagonist [125I]-hGLP-2(3-33,M10Y) had higher Bmax and faster on-rate for the hGLP-2R compared to the agonist [125I]-hGLP-2(1$33, \mathrm{M} 10 \mathrm{Y})$. Using autoradiography in mice strong labeling was observed in subepithelial myofibroblasts (SEMF) and pancreas islet cells. Both radioligands were selective for the GLP-2R, except for a low affinity binding to the GLP-1R (IC50 of 130 and $330 \mathrm{nM}$, respectively) Conclusion and implications: We successfully developed two new high affinity radioligands for GLP-2R studies and identified SEMF and pancreatic islets as target for GLP-2. It is uncertain whether binding in the pancreas islets results from GLP-2R or GLP-1R binding.
\end{abstract}

\section{INTRODUCTION}

Glucagon-like peptide-2 (GLP-2) is a gut hormone consisting of 33 amino acids (GLP-2(1-33)), which is a product of the pro-glucagon gene secreted from the enteroendocrine L-cells of the small intestine upon nutrient ingestion. GLP-2(1-33) is cleaved by the ubiquitous protease dipeptidyl peptidase-4 (DPP-4), resulting in the degradation product GLP-2(3-33) (Hartmann et al. 2000; Holst et al. 2000). In mice, administration of GLP-2(1-33) promotes growth of the small and large intestine (Drucker et al. 1996; Thulesen et al. 2002), stimulates proliferation of the crypt cell, nutrient absorption as well as promoting healing and maintenance of epithelial integrity (Drucker, 2013; Dubé, 2006). These intestinotrophic actions of GLP-2 have been exploited therapeutically with the use of the DPP-4 resistant GLP-2(1-33) analogue Teduglutide, that since 2012 has been used in the treatment of short bowel syndrome (SBS) in adults (Jeppesen et al. 2001; Kim et al. 2017). In addition, a four month clinical study showed that GLP-2(1-33) 
has an anti-catabolic effect on the bone tissue by inhibiting bone resorption (as measured by the bone marker CTX (C-terminal telopeptide)), as shown by our group and others (Askov-Hansen et al. 2013; Gottschalck et al. 2008; Gottschalck et al. 2008; Henriksen et al. 2009; Henriksen et al. 2003; Henriksen et al. 2007).

The metabolite GLP-2(3-33) acts as a partial agonist of the GLP-2 receptor (GLP-2R) (EC F0 $_{50} \sim 6 \mathrm{nM}$ and Emax of $15 \%$ of GLP-2(1-33)) with competitive antagonistic properties on the human (hGLP-2R) in vitro andin vivo (Thulesen et al. 2002). Structurally, GLP-2 is closely related to the peptide hormones glucagon-like peptide-1 (GLP-1) and glucose-dependent insulinotropic polypeptide (GIP). GIP (secreted from enteroendocrine K-cells) and GLP-1 (co-secreted with GLP-2 from L-cells) are important insulinotropic hormones, whereas GLP-2 is inactive in this respect (Schiellerup et al. 2019). GLP-1 analogs are widely used as treatment for type 2 diabetes mellitus (T2DM) and obesity, and more recently, a dual-agonist of GLP-1 and GIP showed promising effects within this field (Coskun et al. 2018; Willard et al. 2020)

The GLP-2R is a G protein-coupled receptor (GPCR), belonging to the subclass B1 of the GPCR family, which comprises of 15 receptors including the GLP-1 receptor (GLP-1R), the GIP receptor (GIPR), the glucagon receptor (GCGR), the Secretin receptor (SecretinR), and the vasoactive intestinal peptide 1 and 2 receptors (VPAC1R and -2R) (Culhane et al. 2015; Gabe et al. 2020; Kenakin et al. 2010). High resolution structures of class B1 GPCRs (but not yet GLP-2R) combined with mutation studies, have enabled the analysis of the active, intermediate and inactive conformations of the receptor, thereby revealing residues that are essential for ligand binding and/or activation (Gabe et al. 2020; Parthier et al. 2009; Song et al. 2017; Zhang et al. 2018; Zhang et al. 2017). Currently, the leading paradigm regarding activation of class B1 GPCRs is the "two-step" mechanism, suggesting that the peptide ligand switches between an overall disordered and more ordered alpha-helical secondary structure, where the N-terminal part of the extracellular domain (ECD) of the receptor recognizes the C-terminal or middle part of the ligand for interaction, where after the Nterminal part of the ligand orientates towards and docks into the transmembrane domains (TMDs) of the receptor (Gabe et al. 2020; Parthier et al. 2007). The two-step mechanism is a simplified model of a complex network of conformational changes that takes place upon activation (Liang et al. 2018; Liang et al. 2018; Sasaki et al. 1975; Schwartz et. al. 2017; Venneti et al. 2011; Zhang et al. 2017; Zhao et al. 2019). Signaling through class B1 receptors, including the GLP-2R, mainly occurs through Gas-coupling, thereby evoking multiple signaling cascades, including increased levels of the downstream second messenger cyclic adenosine monophosphate (cAMP) (Correll et al. 2014). By immunofluorescence microscopy, Estall et al. showed that the C-terminus of the GLP-2R recruits $\beta$-arrestin-2 following agonist stimulation, but that the recruitment is not required for Gas-coupling, desensitization, and receptor endocytosis of GLP-2R (Estall et al. 2005). Functional consequences of $\beta$-arrestin recruitment by the GLP-2R have not yet been described, although important effects of recruitments have been demonstrated for other class B1 GPCRs, including the GIPR (Gabe et al. 2018) and the GLP-1R (Roussel et al. 2016; Whalen et al. 2011).

Although the GLP-2R was cloned for the first time in 1999, the precise tissue and cellular localization of GLP-2R expression remains controversial, undoubtedly due to the lack of specific antibodies. Messenger RNA (mRNA) transcripts of the GLP-2R are found within gastro-intestinal tissues (stomach, duodenum, jejunum, ileum, colon and intestinal ganglion cells) of various species, including human and rodents (Bjerknes et al. 2002; El-Jamal et al. 2014; Guan et al. 2006; Munroe et al. 1999; Ørskov et al. 2005; Pedersen et al. 2015; Yusta et al. 2000). El-Jamal N et. al. have demonstrated GLP-2R mRNA transcripts within the intestinal subepithelial myofibroblasts (SEMF) cell line, CCD-19Co (El-Jamal et al. 2014), supporting earlier studies (Ørskov et al. 2005), describing the expression of the GLP-2R protein throughout the small and large intestine, and particularly within the SEMFs of the GI tract by immunohistochemistry. Also, the mRNA transcript of the GLP-2R has been reported in extraintestinal tissues (fat, lymph nodes, bladder, spleen liver and hepatocytes) (El-Jamal et al. 2014; Yusta et al. 2000; Yusta et al. 2019). Interestingly, De Heer et. al. demonstrated the GLP-2R mRNA transcript in human and rat pancreas (De Heer et al. 2007), a tissue that is known for high expression levels of the GLP-1R (Richards et al. 2014). Thus, there seems to be expression of the GLP-2R in several tissues.

Here, we present two new, high-affinity human GLP-2 (hGLP-2) radioligands with tyrosine (Tyr)-substitution 
at position 10 in the two naturally occurring GLP-2 peptides, the natural agonist GLP-2(1-33) and the antagonist and partial agonist GLP-2(3-33). With these, we determined active and in-active receptor conformations, the interchange between the two, and differential binding kinetics for the two radioligands. Furthermore, we performed autoradiography studies in mice to determined GLP-2R protein expression in vivo .

\section{MATERIALS AND METHODS}

\section{Plasmids and peptides}

cDNA of the receptors were inserted into the pcDNA3.1(+) vector. All ligand peptides were purchased from CASLO ApS (Technical University of Denmark, DTU-Science Park) with a minimum purity of $95 \%$.

\section{Cell culturing, transfection and generation of stable cell lines}

COS-7 cells were cultured at $10 \% \mathrm{CO}_{2}, 95 \%$ air humidity and $37 \mathrm{deg} \mathrm{C}$ in Dulbecco's Modified Eagle Medium (DMEM) 1885 supplemented with $10 \%$ fetal bovine serum (FBS), $1 \%$ penicillin $(180 \mathrm{U} / \mathrm{mL}) /$ streptomycin $(45$ $\mu \mathrm{g} / \mathrm{mL}$ ). The cells were transfected using the calcium phosphate precipitation method as previously described (Jensen et al. 2008). Briefly, the cells were seeded in T175/T75/T25 flasks one day before transfection with 40/20/10 $\mu \mathrm{g}$ receptor DNA. Transiently transfected COS-7 cells were used in cAMP accumulation and for whole cell homologous and heterologous binding.

HEK-293 cells stably expressing hGLP-2R or pcDNA3.1(+) were generated by transfection as described above. The cells were cultured at $10 \% \mathrm{CO}_{2}, 95 \%$ air humidity and $37^{\circ} \mathrm{C}$ in Dulbecco's Modified Eagle Medium (DMEM), containing 1\% GlutaMAX, and supplemented with 10\% fetal bovine serum (FBS) $1 \%$ penicillin $(180 \mathrm{U} / \mathrm{mL}) /$ streptomycin $(45 \mu \mathrm{g} / \mathrm{mL})$ and $0.4 \mathrm{mg} / \mathrm{mL}$ G418 for selection. Stably transfected HEK-293 cells were utilized for membrane preparation used in kinetic binding experiments.

\section{Membrane preparation}

hGLP-2R and pcDNA3.1(+) membranes were prepared through several centrifugation steps. The cells were scraped with PBS supplemented with a cOmplete EDTA free protease inhibitor (Roche, Basel, Switzerland) and then homogenized using a Douncer homogenizer. The homogenate was centrifuged for 3 min at $500 \mathrm{rpm}$ $\left(54 \mathrm{~g} ; 4^{\circ} \mathrm{C}\right)$ and subsequently the supernatant was centrifuged for $45 \mathrm{~min}$ at $14500 \mathrm{rpm}$ at $\left(24446 \mathrm{~g} ; 4^{\circ} \mathrm{C}\right)$. The resulting pellet was resuspended in storage buffer (20 mM HEPES buffer ( $\mathrm{pH} 7.2), 0.4 \mathrm{mM} \mathrm{CaCl}_{2}, 2$ $\mathrm{mM} \mathrm{MgCl}_{2}$ and cOmplete EDTA free protease inhibitor) and stored at $-80^{\circ} \mathrm{C}$. Protein determination was performed according to a standard Pierce BCA protein assay protocol (Thermo Scientific, Rockford, IL).

\section{cAMP measurements}

For the cAMP measurements, COS-7 cells were transfected with receptor plasmid or pcDNA3.1(+) and seeded with 25000 cells per well in a CulturPlate-96 (PerkinElmer; Waltham, MA) one day after transfection. The following day, the cells were washed once with HEPES-buffered saline and incubated for 30 min at $37^{\circ} \mathrm{C}$ with HEPES-buffered saline supplemented with $1 \mathrm{mmol} / 1$ 3-isobutyl-1-methylxanthine (IBMX) buffer. To test for intrinsic activity, endogenous hGLP-2(1-33) or hGLP-2(3-33) or the M10Y-substituted variants (hGLP-2(1-33,M10Y) or hGLP-2(3-33,M10Y)) were added in increasing concentrations, and the plates were incubated for additional $30 \mathrm{~min}$ at $37^{\circ} \mathrm{C}$. To test hGLP-2(3-33) and hGLP-2(3-33,M10Y) as antagonists the cells were preincubated for 10 min with a fixed concentration of antagonist followed by the addition of increasing concentrations of agonist. Afterwards, the HitHunter cAMP XS-assay (DiscoverX, Birmingham, UK) was carried out according to the manufacturer's instructions. All experiments were made in duplicates, and luminescence was measured by a Perkin Elmer EnVision 2104 Multilabel reader (PerkinElmer; Waltham, MA).

\section{Oxidative iodination}

The radioligands were created by oxidative iodination with the oxidizing agent ChloramineT. Here the iodine 
isotope $\left[{ }^{125} \mathrm{I}\right]$ becomes incorporated in the Tyr residue at position 10 of hGLP-2(1-33,M10Y) or hGLP-2(3$33, \mathrm{M} 10 \mathrm{Y})$. $2 \mathrm{nmol}$ peptide was dissolved in $10 \mu \mathrm{L}$ iodination buffer $(100 \mathrm{mM}$ phosphate buffer) and $0.4 \mathrm{nCi}$ $\mathrm{Na}^{125} \mathrm{I}$ was added. A stepwise, so-called stoichiometric oxidation reaction was performed by sequential addition of 6 aliquots of $5 \mu \mathrm{L}$ ChloraminT $(30 \mu \mathrm{g} / \mathrm{mL})$ with 1 min intervals during constant stirring. Under these conditions $\left[{ }^{125} \mathrm{I}\right]$ is incorporated at the hydroxyl group in the ortho position of the Tyr residue. The reaction was terminated by the addition of $400 \mu \mathrm{L}$ phase $\mathrm{A}(0,1 \%$ trifluoracetic acid (TFA)). The reaction was carried out in at $\mathrm{pH} 7.4$ to avoid labeling of histidine residues at basic conditions $(\mathrm{pH}>8.5)$. The product was fractionated on a high-performance liquid chromatography (HPLC) (§̊kta, GE Healthcare, Boston US) with a C18 column for reverse-phase (RP) HPCL (RP-HPCL). The column was initially flushed with $80 \%$ phase $\mathrm{A}$ and $20 \%$ phase $\mathrm{B}$ (Acetonitrile $+0,1 \% \mathrm{TFA}$ ), and terminally by applying increasing concentrations of phase B. The pressure of the RP-HPCL was kept constant at $8 \mathrm{MPa}$ with a flow of $1 \mathrm{~mL} / \mathrm{min}$. Before binding assays were performed the eluted fractions were tested in homologous competition binding (see next section for method).

\section{Homologous and heterologous binding}

For the competition binding experiments, COS-7 cells were transfected with receptor plasmid or pcDNA3.1(+) and seeded with 150000 cells per well in CulturPlate-24 (PerkinElmer; Waltham, MA) one day after transfection. The number of cells seeded per well was selected on the basis to obtaining $5-10 \%$ specific binding of the radioligands. Day 2 after transfection, the cells were washed twice in prechilled binding buffer (50 mM HEPES buffer, supplemented with $1 \mathrm{mM} \mathrm{CaCl}_{2}, 5 \mathrm{mM} \mathrm{MgCl}_{2}$ and $0,5 \%$ (w/v) BSA) at pH 8 and incubated for $15 \mathrm{~min}$ at $4 \mathrm{C}^{\circ}$. Increasing concentration of unlabeled ligand followed by a stable concentration of the radioligand $(20000 \mathrm{cpm} /$ well $)$ were added to the cells, which were then incubated for additional 3 hours at $4 \mathrm{C}^{\circ}$. After incubation, the cells were washed twice in prechilled binding buffer, lysed, and counted using a Wizard gamma counter (PerkinElmer; Waltham, MA).

\section{Kinetic binding experiments}

The association assays were performed by preparing a mixture of $10 \mu \mathrm{g}$ hGLP-2R or pcDNA3.1(+) and $0.5 \mathrm{mg}$ wheatgerm agglutinin coated (WGA) PVT SPA beads (PerkinElmer; Waltham, MA). This mixture was pre-coupled on a shaker in a total volume of $50 \mu \mathrm{L}$ binding buffer (50 mM HEPES buffer ( $\mathrm{pH} 7.2)$ ), supplemented with $1 \mathrm{mM} \mathrm{CaCl} 2,5 \mathrm{mM} \mathrm{MgCl}_{2}$ and $0,5 \%$ (w/v) BSA) for $30 \mathrm{~min}$ at $30^{\circ} \mathrm{C}$. The pre-coupling was followed by the distribution of membrane suspension in a CulturPlate-96 (PerkinElmer; Waltham, MA) in a total volume of $90 \mu \mathrm{L}$ binding buffer and spun down afterwards (1 500 RPM, $485 \mathrm{~g}, 5 \mathrm{~min}$, room temperature). The reaction was initiated by the addition of $0.19 \pm 0.001 \mathrm{nM}\left[{ }^{125} \mathrm{I}\right]$-hGLP-2(1-33,M10Y) or $0.21 \pm 0.004 \mathrm{nM}\left[{ }^{125} \mathrm{I}\right]-\mathrm{hGLP}-2(3-33, \mathrm{M} 10 \mathrm{Y})$, and the amount of radioligand bound to receptor was measured every minute up to $100 \mathrm{~min}\left[{ }^{125} \mathrm{I}\right]-\mathrm{hGLP}-2(3-33, \mathrm{M} 10 \mathrm{Y})$ or $120 \mathrm{~min}\left[{ }^{125} \mathrm{I}\right]-\mathrm{hGLP}-2(1-33, \mathrm{M} 10 \mathrm{Y})$ at $30^{\circ} \mathrm{C}$, using a TopCount NXT Microplate Scintillation \& Luminescence Counter (PerkinElmer; Waltham, MA).

For the dissociation assays, the membrane suspension was distributed to the wells in a total volume of 85 $\mu \mathrm{L}$ binding buffer. The mixture was then pre-incubated for $60 \mathrm{~min}$ at $30^{\circ} \mathrm{C}$ after addition of $0.19 \pm 0.001$ nM [ $\left.{ }^{125} \mathrm{I}\right]$ GLP-2 $\left[{ }^{125} \mathrm{I}\right]$-hGLP-2(1-33,M10Y) or $0.21 \pm 0.004 \mathrm{nM}\left[{ }^{125} \mathrm{I}\right]$-hGLP-2(3-33,M10Y). The dissociation was initiated by the addition of $5 \mu \mathrm{L}$ of $1 \mu \mathrm{M}$ unlabeled hGLP-2(1-33,M10Y) or hGLP-2(3-33,M10Y). The amount of receptor-bound radioligand was measured every minute up to $500 \mathrm{~min}$.

\section{Immunohistology and autoradiography}

All procedures in the mice were approved by the Danish National Animal Experiments Inspectorate (license no. 2018-15-0201-01397). All mice were kept in the animal facility and received tap water and standard chow ad libitum.

Surgical procedure. Female C57BL/6JRj mice $(\mathrm{n}=9)$ weighing 18-26 g were purchased from Janvier (Saint Berthevin Cedex, France) and left to acclimatize for at least one week before experimental procedures were performed. The mice were anaesthetized with an intraperitoneal injection of ketamine-xylazine (100:10 $\mathrm{mg} / \mathrm{kg}$, Pharma service SUND, UCPH, Copenhagen, Denmark). The abdomen was opened by a midline 
The sequence of hGLP-2 (figure 1a) does not include a Tyr residues and therefore unsuitable for oxidative iodination using iodine-125 [ $\left.{ }^{125} \mathrm{I}\right]$. hGLP-2 shows high sequence similarities to the class B1 hormones hGIP, hGCG and hGLP-1 (figure 1a). Generally, a high level of promiscuity among class B1 ligand-receptor pairs can be found (Sandoval et al. 2015; Skov-Jeppesen et al. 2019; Svendsen et al., 2018), which enable us to look for a suitable position for $\left.{ }^{125} \mathrm{I}\right]$-labeling of hGLP-2 At position $10 \mathrm{in} \mathrm{hGIP}$ and hGCG, a Tyr residue is found, which is the target for oxidative $\left[{ }^{125} \mathrm{I}\right]$-labeling of these peptides (Sparre-Ulrich et al. 2017, 2016). At the corresponding site in hGLP-2 a methionine (Met) residue is found, which we replaced with a Tyr residue (referred to as M10Y) (figure 1a). Because GLP-2(1-33) is rapidly cleaved into the antagonist (and partial agonist) hGLP-2(3-33) by DPP-4, (Hartmann et al. 2000), we modified both peptides to create the two consecutive peptides (hGLP-2(1-33,M10Y) and hGLP-2(3-33,M10Y)) with the intension of creating both an agonistic and an antagonistic radioligand.

First, the activity of the two altered peptides was measured in terms of cAMP accumulation. COS-7 cells transiently expressing hGLP-2R were stimulated with increasing concentrations of the two modified GLP-2 variants in comparison with the endogenous GLP-2 peptides. Endogenous hGLP-2(1-33) and hGLP-2(3-33) accumulated cAMP as previously shown (figure 1b,c and table 1) (Skov-Jeppesen et al. 2019). hGLP-2(1$33, \mathrm{M} 10 \mathrm{Y}$ ) displayed a strong and full activation of hGLP-2R with only a 2.5 -fold decreased potency compared to hGLP-2(1-33) (figure 1b and table 1). Similar to the endogenous hGLP-2(3-33), hGLP-2(3-33,M10Y) was a partial agonist with similar potency and efficacy as hGLP-2(3-33) (figure 1c and table 1). These data show that the two M10Y-substituted variants function in a similar manner as their corresponding endogenous peptides. As GLP-2(3-33) has previously been described as a competitive antagonist for the hGLP-2R (Skov-Jeppesen et al. 2019), we tested the antagonistic properties of hGLP-2(3-33,M10Y) by determining the impact of increasing concentrations $(100 \mathrm{mM}$ and $1 \mu \mathrm{M})$ of hGLP-2(3-33,M10Y), on the potency of hGLP-2(1-33) on the hGLP-2R. Consistent with a competitive antagonistic nature, hGLP-2(3-33,M10Y) resulted in a rightward shift of the dose-response curve of hGLP-2(1-33) (figure 1d and table 1).

\section{High and similar binding properties of iodinated hGLP-2(1-33,M10Y) and hGLP-2(3- 33,M10Y)}

Since both modified peptides had similar functional properties as the endogenous peptides, we continued with hGLP-2(1-33,M10Y) and hGLP-2(3-33,M10Y) for radioligand development using chloramineT for stoichiometric oxidation of the Tyr residue. To verify the binding properties of the two radioligands, we performed homologous whole cell competition binding in cells transiently expressing the hGLP-2R. Both radioligands showed high-affinity binding for hGLP-2R (figure 2 a,b and table 2), thereby demonstrating successful development of two new radioligands with high and similar binding affinities for the hGLP-2R. A significant higher Bmax was found for the antagonist $\left[{ }^{125} \mathrm{I}\right]$-hGLP-2(3-33,M10Y) $\left(96,6 \mathrm{fmol} / 10^{5}\right)$ compared to the agonist $\left[{ }^{125} \mathrm{I}\right]$-hGLP-2(1-33,M10Y) $\left(58,0 \mathrm{fmol} / 10^{5}\right)$ (figure $2 \mathrm{c}$ ). These data are in accordance with a generally higher amount of binding sites for GPCR antagonists compared to agonists (Baker et al. 2007).

Since ligand-receptor binding kinetics is a key determinant of ligand efficacy (Velden et al. 2020), we determined the association $\left(\mathrm{k}_{\mathrm{on}}\right)$ and dissociation $\left(\mathrm{k}_{\mathrm{off}}\right)$ rates of both radioligands, using cell membranes stably expressing the hGLP-2R. For both ligands, the kinetic profiles were best fitted with a one-phase association and a one-phase dissociation. Saturation of $\left[{ }^{125} \mathrm{I}\right]-\mathrm{hGLP}-2(1-33, \mathrm{M} 10 \mathrm{Y})$ was reached at around $60 \mathrm{~min}$, whereas for $\left[{ }^{125} \mathrm{I}\right]$-hGLP-2(3-33,M10Y) saturation was reached already at $40 \mathrm{~min}$ (figure $2 \mathrm{~d}$ ). This was also reflected in the observed on-rates with a ${ }^{2}$ fold higher $\mathrm{k}_{\text {obs }}$ for $\left[{ }^{125} \mathrm{I}\right]$-hGLP-2(3-33,M10Y) (0.076 $\left.\pm 0.009 \mathrm{~min}^{-1}\right)$ compared to $\left[{ }^{125} \mathrm{I}\right]$-hGLP-2(1-33,M10Y) $\left(0.027 \pm 0.003 \mathrm{~min}^{-1}\right)$. After reaching equilibrium, the binding was reversed by the addition of $1 \mu \mathrm{M}$ unlabeled hGLP-2(1-33,M10Y) and hGLP-2(3-33,M10Y), respectively (figure 2e). The two ligands had similar dissociation rates $\left(\mathrm{k}_{\text {off }}\right)$ of $0.009 \pm 0.004 \mathrm{~min}^{-1}$ and $0.010 \pm 0.002 \mathrm{~min}^{-1}$, respectively. Finally, we calculated the on-rate $\left(\mathrm{k}_{\mathrm{on}}\right)$ of both radioligands, and found a $\sim 3.5$ fold higher on-rate for the antagonist $\left(0.329 \pm 0.047 \mathrm{nM}^{-1 *} \min ^{-1}\right)$, compared to the agonist $(0.094 \pm$ $0.014 \mathrm{nM}^{*} \min ^{-1}$ ) (figure 2f). Thus, the receptor binding of the antagonist is faster than that of the agonist, presumably reflecting, that the receptor undergoes less conformational changes upon antagonist binding compared to agonist binding. 


\section{Native hGLP-2(1-33) binds to the hGLP2-R with highest affinity among the tested ligands}

In order to determine whether agonists and antagonists competed similarly, we measured heterologous binding (figure 3) by displacing the two radioligands with the four unlabeled peptides; hGLP-2(1-33), hGLP2(3-33), hGLP-2(1-33,M10Y) and hGLP-2(3-33,M10Y). Overall, all four ligands were able to compete with both radioligands, with no significant differences in their binding affinities whether using the agonist or the antagonist radioligand (figure $3 \mathrm{a}$ and table 2). However, native hGLP-2(1-33) had a 4- to 5-fold higher affinity compared to the other three hGLP-2 variants (figure 3 and table 2). The decreased affinity of hGLP-2(1-33,M10Y) compared to hGLP-2(1-33) is consistent with the slightly decreased potency for hGLP-2(1-33,M10Y) compared to hGLP-2(1-33) (figure 1b).

\section{Minimal binding to other class B1 GPCRs for $\left[{ }^{125} \mathrm{I}\right]-\mathrm{hGLP}-2(1-33, M 10 Y)$ and $\left[{ }^{125} \mathrm{I}\right]-\mathrm{hGLP}-$ 2(3-33,M10Y)}

Given the high sequence similarity between class B1 receptors and their peptide ligands, we next determined whether the two radioligands cross-react with the closely related class B1 GPCRs; hGIPR, hGLP-1R, hGCGR and hSecretinR, VPAC-1R, and VPAC-2R (figure 4a). While we observed no specific binding for five of the six receptors, a low, but significant binding was observed for both radioligands to the hGLP-1R (Emax of $37.8 \%$ and $26.7 \%$ of the hGLP-2R binding) (figure $4 \mathrm{~b}$ and supplementary figure 1 ).

Furthermore, we tested the binding properties of both radioligands on the mouse and rat GLP. Also here, we observed high-affinity binding (figure 5a,b and table 2). The similar $\mathrm{IC}_{50}$ values of hGLP-2(1-33) on the GLP-2R from the three species suggests overall strong structural similarities between the receptors (table $2)$.

\section{Autoradiography in mice reveals receptor expression in sub-epithelial myofibroblasts.}

Having confirmed the binding of $\left[{ }^{125} \mathrm{I}\right]$-hGLP-2(1-33,M10Y) to rodent GLP-2Rs, we did autoradiography studies in mice with this radioligand. In all mice examined $(n=6)$, we observed strong labeling in the SEMFs of the gastrointestinal (GI) tract (figure 5c,e and supplementary figure 2) and in the islet cells of the endocrine pancreas (figure 5d,f and supplementary figure 2). These data are consistent with previous data (El-Jamal et al. 2014; De Heer et al. 2007; Ørskov et al. 2005), and thereby confirming at the protein level what was shown at the level of GLP-2R mRNA transcript. Injection of unlabeled GLP-2(1-33) prior to the radioligand abrogated labeling in both tissues (figure 5e,f), supporting the specific binding of [ $\left.{ }^{125} \mathrm{I}\right]$-hGLP-2(1-33,M10Y).

Since the pancreas is known for high expression levels of the GLP-1R and given the observed binding of both hGLP-2-based radioligands to the hGLP-1R (figure 4), we tested the binding of the radioligands to the mouse and rat GLP-1R. Here, we were surprised by a very high specific binding of both radioligands to the mouse GLP-1R (mGLP-1R), while no binding was observed for the rat GLP-1R (rGLP-1R) (supplementary figure 3). The binding of both radioligands to mGLP-1R reached the same Emax as for the mouse GLP-2R (mGLP-2R), but have a 32-fold lower affinity (table 2).

\section{Specific binding of GLP-2 to the GLP-1R}

The binding to the mGLP-1R combined with the low, but specific binding to the hGLP-1R, inspired us to further characterize the action of hGLP-2 in the hGLP-1R system using the same experimental setup as for the hGLP-2R (figure 1). The two full-length variants hGLP-2(1-33) and hGLP-2(1-33,M10Y) both showed weak agonistic properties on the hGLP-1R with $>1000$-fold lower potency compared to endogenous GLP-1 (figure $6 \mathrm{a}$ and table 1). These data corresponds to previous data (Gasbjerg et al. 2018). In contrast, the two N-terminally truncated variants hGLP-2(3-33) and hGLP-2(3-33,M10Y) did not activate the hGLP-1R (figure $6 \mathrm{~b}$ and table 1 ). To confirm that the hGLP-2 mediated cAMP response was mediated through the GLP-1R, we reversed the signal by employing the high affinity GLP-1R antagonist exendin(9-39) (Schirra et al. 1998). A rightward shift was observed for the dose-response curve of hGLP-2(1-33) in the presence of exendin(9-39) (figure 6c and table 1), demonstrating that the cAMP accumulation induced by hGLP2(1-33) is mediated through the hGLP-1R, in a similar manner, as that of GLP-1. In contrast, increasing 
concentrations (up to $1 \mu \mathrm{M}$ ) of hGLP-2(3-33,M10Y) did not affect the activity of GLP-1 on the hGLP-1R (figure $6 \mathrm{~d}$ and table 1 ).

\section{DISCUSSION}

Despite the emerging evidence for the biological importance of GLP-2 as a trophic hormone for the gut and bones, very little structural information is available of the GLP-2R. An increasing number of high-resolution structures of class B1 GPCRs, have been published (Liang et al. 2018; Qiao et al. 2020; Wu et al. 2020; Zhang et al. 2018; Zhang et al. 2017; Zhao et al. 2020), yet the structure of the GLP-2R remains to be determined. However, a handful of studies focusing on the GLP-2 structure and its interaction with the GLP-2R have elucidated structural requirements for GLP-2's interaction with its receptor. In 2000, DaCambra et. al. performed an Alanine(Ala)-scan within the DPP-4 resistant $\mathrm{h}\left[\mathrm{Gly}^{2}\right] \mathrm{GLP}-2(1-33)$ and showed reduced receptor activation (cAMP accumulation), of the rGLP-2R by alterations in the N-terminus part of the peptide (Dacambra et al. 2000). Here, Ala replacement of the Histidine1 and the Asparticacid3 of hGLP-2, severely reduced receptor activation with only modest changes in binding affinity. These data demonstrate the importance of the GLP-2 N-terminus for receptor activation, as also illustrated by the partial agonism (and competitive antagonism) of GLP-2(3-33) (Thulesen et al. 2002) (figure 1). Ala-scan within the C-terminus part of $\mathrm{h}\left[\mathrm{Gly}^{2}\right]$ GLP-2 severely reduced the binding affinity demonstrating a central role of the C-terminus part for receptor binding. In 2011, Venneti et. al. presented the first three-dimensional solution structure of GLP-2 by nuclear magnetic resonance (NMR) (Venneti et al. 2011). This structure supported the distinct roles of the N- and C-terminus part of GLP-2 and revealed a stable alpha-helical conformation at the central region (between Phe6 and Ile27) and a less well-defined helical conformation in the C-terminus region. The binding interface with the extracellular domain (ECD) of the receptor was predicted to be between Leucine17 and Lysine30, while the N-terminus part of GLP-2 from Histiine1 to Aspargine16 lacked contact with the extracellular domains of the GLP-2R. The central roles of the N- and C-terminus part of GLP-2 in respectively, receptor activation and receptor binding were supported by Yamazaki et. al. in 2013 (Yamazaki et al. 2013), showing a decreased intrinsic placental alkaline phosphatase (PALP) activity (driven by cAMP) for GLP-2(3-33), (6-33) and (11- to 13-33). Most recently, Wisniewski et. al. replaced each residue in the DPP-4 resistant [Gly2,Nle10]hGLP-2(1-30) analog with its d-enantiomer in a systematic approach to gain insight into the GLP-2R recognition revealing a loss of potency at position $5,8,9,12$, and 14 in the N-terminus, and similar loss for position 17-20, 25, and 29 in the C-terminus (Wisniewski et al. 2016). Consistent with this, the C-terminal of GLP-2 orientates towards a hydrophilic cavity in the NMR structure (Venneti et al. 2011). Thus, the N-terminal part of GLP-2 plays a central role in receptor activation, while the C-terminus adopts an alpha-helical conformation that plays a central role of receptor binding of GLP-2 consistent with the suggested "two-step" activation model of class B1 GPCRs, a model that is now much more refined (Liang et al. 2018; Qiao et al. 2020; Wu et al. 2020; Zhang et al. 2018; Zhang et al. 2017; Zhao et al. 2020).

The M10Y-modification barely changed the functional properties of the two endogenous hGLP-2 variants, demonstrating, in agreement with the model discussed above, that the Met10 of GLP-2 neither plays an important role in ligand binding nor receptor activation. According to the NMR structure, Met10 is positioned at the beginning of the alpha-helix and is not part of the binding interface of the GLP-2R (Venneti et al. 2011). Consistent with this, Wisniewski et. al. replaced the oxidation and alkylation-prone Met residue at position 10 of hGLP-2 by the isosteric Nor-leucine (Nle) (Wisniewski et al. 2016). Met is characterized by a sulfur atom in the sidechain, which is highly sensitive to reactive oxygen species (ROS) that often changes structural and functional properties of proteins (Black et al. 1991; Kim et al. 2014). ROS-mediated oxidation occurs by the addition of a single oxygen molecule to the sulfur atom, forming methionine sulfoxide (MetSO) (Kim et al. 2014), which creates a chiral center around the sulfur atom and overall results in a stiffer and more polar side chain compared to the unoxidized Met residue (Black et al. 1991). These changes can have profound structural and functional consequences (Chao et al. 1997; Hoshi et al. 2001; Gu et al. 2015; Sugamura et al. 2011). To protect for oxidative damage of the Met in GLP-2 during the oxidative iodination, and since Met is dispensable for GLP-2 function (Drucker et al. 2013; Venneti et al. 2011; Wisniewski et al. 2016; Yamazaki et al. 2013), we replaced Met10 with a Tyr residue. Thereby we created 
a target site for oxidative iodination using $\left[{ }^{125} \mathrm{I}\right]$ in the full agonist (GLP-2(1-33)) and in the antagonist and partial agonist (GLP-2(3-33)). These modifications created the two peptides; hGLP-2(1-33,M10Y) and hGLP-2(3-33,M10Y). These two M10Y-substituted peptides acted as their wildtype counterparts, and with these, we were in a unique position allowing us to investigate both agonist [ $\left.\mathrm{I}^{125}\right]$-hGLP-2(1-33,M10Y) and antagonist $\left[\mathrm{I}^{125}\right]$-hGLP-2(3-33,M10Y) binding.

The similar affinities $\left(\mathrm{K}_{\mathrm{D}}\right)$ support the main role of the N-terminus in receptor activation and not in receptor binding (Couvineau et al. 2011). Moreover, the higher Bmax for the antagonist follows the general trend for more antagonist binding conformations versus agonist conformations of GPCRs ( Rosenkilde et al. 1994). Interestingly, for the first time among class B1 GPCRs, we describe the binding kinetics of a peptide agonist in comparison with a peptide antagonist and show, that the on-rate for the antagonist is significantly faster than for the agonist. Binding kinetics parameters, including $k_{\text {on }}$ and $k_{\text {off }}$, have been highlighted to be more important in describing a ligand's in vivo efficacy and the onset of action, than the classical parameters such as $K_{D}$ and $K_{I}$ (Velden et al. 2020). The slower on-rate for the agonist could reflect a more complex binding compared to the antagonist in line with expected induction of active receptor states (Zhang et al. 2018). When comparing the apparent affinities for the agonists and the antagonists obtained in competition with two radioligands, we observed similar affinities irrespective of choice of radioligand. This suggests that all four ligands (initially) interact similarly with the ECDs of the hGLP-2R, and that the receptor easily interchanges between (sequential) conformations induced by the agonist and the antagonist.

The location of the GLP-2R remains controversial in both rodent and humans. It has been reported that the GLP-2R mRNA transcript and protein is expressed in SEMFs (El-Jamal et al. 2014; Ørskov et al. 2005). Here we confirm receptor expression at the protein level in SEMFs in the intestine and in the pancreatic islet cells of mice by using the agonistic radioligand [ $\left.{ }^{125}\right]$-hGLP-2(1-33,M10Y). The prevention of $\left[{ }^{125} \mathrm{I}\right]$-hGLP2(1-33,M10Y) labeling by co-injection with excess amounts of unlabeled hGLP-2(1-33,M10Y) demonstrates the specificity of $\left[{ }^{125} \mathrm{I}\right]$-hGLP-2(1-33,M10Y) binding. The strong staining of the pancreatic islet cells by $\left[{ }^{125} \mathrm{I}\right]$-hGLP-2(1-33,M10Y) could result from GLP-2R expression in the pancreatic islet cells, in agreement with what was previously shown at the mRNA level (De Heer et al. 2007). Alternatively, it could result from cross-interaction of GLP-2 with the GLP-1R, or a combination of the two. The strong binding properties of both radioligands to the mGLP-1R, and the low potency activation of the hGLP-1R by GLP-2(1-33) and GLP-2(1-33, M10Y), demonstrate that the pancreatic staining could be a result of GLP-1R binding. Also, promiscuity is known within GPCRs, demonstrated by the activation of the GIPR by GLP-2 (SkovJeppesen et al. 2019), the binding and activation of both the GLP-1R and the GCGR by oxyntomodulin (Holst et al. 2018; Jorgensen et al. 2007), and the activation of the mGLP-1R by glucagon (Svendsen et al. 2018). Thus, cross-activation is a common phenomenon within class B1 GPCRs, which is reflected in the high sequence similarities observed among the receptors and across species. For rodent GLP-2R's, $81 \%$ and $79 \%$ sequence identities are found for the mGLP-2R and rGLP-2R, respectively, explaining the high-affinity binding observed for both radioligands to the rodent GLP-2R's.

As we observed no binding of either hGLP-2 radioligand to the rGLP-2R, future autoradiography studies in rats would eliminate the binding of GLP-2 to the GLP-1R. Another possibility would be to use GLP1R knock-out (KO)-mice, or eliminate hGLP-1R binding by modifications of GLP-2 at the C-terminus, as suggested recently in study where replacement of position 11 and/or 16 of hGLP-2(1-30) eliminated hGLP1R actively, while retaining high hGLP-2R activity (Wisniewski et al. 2016). Thus, it is possible to decrease GLP-2 binding to the GLP-1R without compromising the GLP-2R binding.

\section{CONCLUSION}

We have developed two new radioligands (an agonist and an antagonist) for the GLP-2R; both with high affinity to the human, rat and mouse GLP-2R. With these, we show differential binding kinetics of agonist and antagonist to the GLP-2R, and confirm GLP-2R expression at the protein level in the GI tract's SEMFs and in the pancreatic islet cells. Moreover, we demonstrate cross-activity with -binding and -activity of GLP2 within the GLP-1R system. These observations are of importance for tissue localization and structural characterization for not only the GLP-2R, but also for other class B1 GPCRs. 


\section{REFERENCES}

Askov-Hansen, C., Jeppesen, P. B., Lund, P., Hartmann, B., Holst, J. J., \& Henriksen, D. B. (2013). Effect of glucagon-like peptide-2 exposure on bone resorption: Effectiveness of high concentration versus prolonged exposure. Regulatory Peptides , 181 (1), 4-8. https://doi.org/10.1016/j.regpep.2012.11.002

Baker, J. G., \& Hill, S. J. (2007). Multiple GPCR conformations and signalling pathways: implications for antagonist affinity estimates. Trends in Pharmacological Sciences , 28 (8), 374-381. https://doi.org/10.1016/j.tips.2007.06.011

Bjerknes, M., \& Cheng, H. (2002). Modulation of specific intestinal epithelial progenitors by enteric neurons. Proceedings of the National Academy of Sciences , 98 (22), 12497-12502. https://doi.org/10.1073/pnas.211278098

Black, S. D., \& Mould, D. R. (1991). Development of hydrophobicity parameters to analyze proteins which bear post- or cotranslational modifications. Analytical Biochemistry , 193 (1), 72-82. https://doi.org/10.1016/0003-2697(91)90045-U

Chao, C. C., Ma, Y. S., \& Stadtman, E. R. (1997). Modification of protein surface hydrophobicity and methionine oxidation by oxidative systems. Proceedings of the National Academy of Sciences of the United States of America , 94 (7), 2969-2974. https://doi.org/10.1073/pnas.94.7.2969

Correll, C. C., \& McKittrick, B. A. (2014). Biased ligand modulation of seven transmembrane receptors (7TMRs): Functional implications for drug discovery. Journal of Medicinal Chemistry, Vol. 57, pp. 68876896. https://doi.org/10.1021/jm401677g

Coskun, T., Sloop, K. W., Loghin, C., Alsina-Fernandez, J., Urva, S., Bokvist, K. B., ... Haupt, A. (2018). LY3298176, a novel dual GIP and GLP-1 receptor agonist for the treatment of type 2 diabetes mellitus: From discovery to clinical proof of concept. Molecular Metabolism , 18 , 3-14. https://doi.org/10.1016/j.molmet.2018.09.009

Couvineau, A., \& Laburthe, M. (2011). The Family B1 GPCR: Structural Aspects and Interaction with Accessory Proteins. Current Drug Targets , 13 (1), 103-115. https://doi.org/10.2174/138945012798868434

Culhane, K. J., Liu, Y., Cai, Y., \& Yan, E. C. Y. (2015). Transmembrane signal transduction by peptide hormones via family B G protein-coupled receptors. Frontiers in Pharmacology, Vol. 6. https://doi.org/10.3389/fphar.2015.00264

Dacambra, M. P., Yusta, B., Sumner-smith, M., Crivici, A., Drucker, D. J., \& Brubaker, P. L. (2000). Structural Determinants for Activity of Glucagon-like Peptide-2 + . 8888-8894. https://doi.org/10.1021/bi000497p

De Heer, J., Pedersen, J., Orskov, C., \& Holst, J. J. (2007). The alpha cell expresses glucagon-like peptide-2 receptors and glucagon-like peptide-2 stimulates glucagon secretion from the rat pancreas.Diabetologia , 50 (2135-2142). https://doi.org/10.1007/s00125-007-0761-6

Deblasi, A., Reilly, K. O., \& Harvey, J. (1989). Calculating receptor number from binding experiments using same compound as radioligand and competitor. Trends in Biochemical Sciences , 10 , 1989-1991. Retrieved from https://pubmed.ncbi.nlm.nih.gov/2773043/

Drucker, D. J., Erlich, P., Asa, S. L., \& Brubaker, P. L. (1996). Induction of intestinal epithelial proliferation by glucagon-like peptide 2. Proceedings of the National Academy of Sciences of the United States of America , 93 (15), 7911-7916. Retrieved from http://www.ncbi.nlm.nih.gov/pubmed/8755576\%0Ahttp://www.pubmedcentral.nih.gov/articlerender.fcgi?artid=PMC38848

Drucker, D. J., \& Yusta, B. (2013). Physiology and Pharmacology of the Enteroendocrine Hormone Glucagon-Like Peptide-2. Annual Review of Physiology , 76 (1), 561-583. https://doi.org/10.1146/annurevphysiol-021113-170317 
Dube, P. E., Forse, C. L., Bahrami, J., \& Brubaker, P. L. (2006). The Essential Role of Insulin-Like Growth Factor-1 in the Intestinal Tropic Effects of Glucagon-Like Peptide-2 in Mice. Gastroenterology ,131 (2), 589-605. https://doi.org/10.1053/j.gastro.2006.05.055

El-Jamal, N., Erdual, E., Neunlist, M., Koriche, D., Dubuquoy, C., Maggiotto, F., ... Desreumaux, P. (2014). Glugacon-like peptide-2: broad receptor expression, limited therapeutic effect on intestinal inflammation and novel role in liver regeneration. Am J Physiol Gastrointest Liver Physiol , 307 , 274-285. https://doi.org/10.1152/ajpgi.00389.2012.-The

Estall, J. L., Koehler, J. A., Yusta, B., \& Drucker, D. J. (2005). The Glucagon-like Peptide-2 Receptor C Terminus Modulates beta-Arrestin-2 Association but Is Dispensable for Ligand-induced Effector Activation . 280 (23), 22124-22134. https://doi.org/10.1074/jbc.M500078200

Gabe, M. B. N., Sparre-Ulrich, A. H., Pedersen, M. F., Gasbjerg, L. S., Inoue, A., Brauner-Osborne, H., ... Rosenkilde, M. M. (2018). Human GIP(3-30)NH2 inhibits G protein-dependent as well as G proteinindependent signaling and is selective for the GIP receptor with high-affinity binding to primate but not rodent GIP receptors.Biochemical Pharmacology , 150 , 97-107. https://doi.org/10.1016/j.bcp.2018.01.040

Gabe, M. B. N., van der Velden, W. J. C., \& Smit, F. X. (2020, March 1). Molecular interactions of fulllength and truncated GIP peptides with the GIP receptor - A comprehensive review. Peptides, Vol. 125, p. 170224. https://doi.org/10.1016/j.peptides.2019.170224

Gasbjerg, L. S., Christensen, M. B., Hartmann, B., Lanng, A. R., Sparre-Ulrich, A. H., Gabe, M. B. N., .. Knop, F. K. (2018). GIP(3-30)NH2 is an efficacious GIP receptor antagonist in humans: a randomised, double-blinded, placebo-controlled, crossover study.Diabetologia , 61 (2), 413-423. https://doi.org/10.1007/s00125-017-4447-4

Gottschalck, I. B., Jeppesen, P. B., Hartmann, B., Holst, J. J., \& Henriksen, D. B. (2008). Effects of treatment with glucagon-like peptide-2 on bone resorption in colectomized patients with distal ileostomy or jejunostomy and short-bowel syndrome. Scandinavian Journal of Gastroenterology , 43 (11), 1304-1310. https://doi.org/10.1080/00365520802200028

Gottschalck, I. B., Jeppesen, P. B., Holst, J. J., \& Henriksen, D. B. (2008). Reduction in bone resorption by exogenous glucagon-like peptide-2 administration requires an intact gastrointestinal tract.Scandinavian Journal of Gastroenterology , 43 (8), 929-937. Retrieved from https://pubmed.ncbi.nlm.nih.gov/25900980/

Gu, S. X., Stevens, J. W., \& Lentz, S. R. (2015). Regulation of thrombosis and vascular function by protein methionine oxidation . https://doi.org/10.1182/blood-2015-01

Guan, X., Karpen, H. E., Stephens, J., Bukowski, J. T., Niu, S., Zhang, G., .. Burrin, D. G. (2006). GLP-2 receptor localizes to enteric neurons and endocrine cells expressing vasoactive peptides and mediates increased blood flow. Gastroenterology , 130 (1), 150-164. https://doi.org/10.1053/j.gastro.2005.11.005

Hartmann, B., Harr, M. B., Jeppesen, P. B., Wojdemann, M., Deacon, C. F., Mortensen, P. B., \& Holst, J. J. (2000). In vivo and in vitro degradation of glucagon-like peptide-2 in humans. Journal of Clinical Endocrinology and Metabolism, 85 (8), 2884-2888. https://doi.org/10.1210/jc.85.8.2884

Henriksen, D. B., \& Alexandersen, P. (2009). Four-month treatment with GLP-2 significantly increases hip BMD: a randomized, placebo-controlled, dose-ranging study in postmenopausal women with low BMD. Bone ,45 (5), 833-842. https://doi.org/10.1016/j.bone.2009.07.008

Henriksen, D. B., Alexandersen, P., Bjarnason, N. H., Vilsboll, T., Hartmann, B., Henriksen, E. E. G., ... Christiansen, C. (2003). Role of gastrointestinal hormones in postprandial reduction of bone resorption. Journal of Bone and Mineral Research : The Official Journal of the American Society for Bone and Mineral Research ,18 (12), 2180-2189. https://doi.org/10.1359/jbmr.2003.18.12.2180

Henriksen, D. B., Alexandersen, P., \& Hartmann, B. (2007). Disassociation of bone resorption and formation by GLP-2: a 14-day study in healthy postmenopausal women. Bone , 40 (3), 723-729. 
https://doi.org/10.1016/j.bone.2006.09.025

Holst, Jens J., Albrechtsen, N. J. W., Gabe, M. B. N., \& Rosenkilde, M. M. (2018, February 1). Oxyntomodulin: Actions and role in diabetes.Peptides, Vol. 100, pp. 48-53. https://doi.org/10.1016/j.peptides.2017.09.018

Holst, Jens Juul. (2000, September 25). Gut hormones as pharmaceuticals From enteroglucagon to GLP-1 and GLP-2. Regulatory Peptides, Vol. 93, pp. 45-51. https://doi.org/10.1016/S0167-0115(00)00185-3

Hoshi, T., \& Heinemann, S. H. (2001, February 15). Regulation of cell function by methionine oxidation and reduction. Journal of Physiology, Vol. 531, pp. 1-11. https://doi.org/10.1111/j.1469-7793.2001.0001j.x

Jensen, P. C., Nygaard, R., Thiele, S., Elder, A., Zhu, G., Kolbeck, R., .. Rosenkilde, M. M. (2008). Molecular Interaction of a Potent Nonpeptide Agonist with the Chemokine Receptor CCR8. Molecular Pharmacology . https://doi.org/10.1124/mol.107.035543.two

Jeppesen, P. B., Hartmann, B., Thulesen, J., Graff, J., Lohmann, J., Hansen, B. S., .. Mortensen, P. B. (2001). Glucagon-like peptide 2 improves nutrient absorption and nutritional status in short-bowel patients with no colon. Gastroenterology, 120 (4), 806-815. https://doi.org/10.1053/gast.2001.22555

Jorgensen, R., Kubale, V., Vrecl, M., Schwartz, T. W., \& Elling, C. E. (2007). Oxyntomodulin differentially affects glucagon-like peptide-1 receptor $\beta$-arrestin recruitment and signaling through Gas. Journal of Pharmacology and Experimental Therapeutics , 322 (1), 148-154. https://doi.org/10.1124/jpet.107.120006

Kenakin, T. (2010, October). G protein coupled receptors as allosteric proteins and the role of allosteric modulators. Journal of Receptors and Signal Transduction, Vol. 30, pp. 313-321. https://doi.org/10.3109/10799893.2010.503964

Kim, E. S., \& Keam, S. J. (2017). Teduglutide: A Review in Short Bowel Syndrome. Drugs , 77 (3), 345-352. https://doi.org/10.1007/s40265-017-0703-7

Kim, G., Weiss, S. J., \& Levine, R. L. (2014). Methionine oxidation and reduction in proteins. Biochimica et Biophysica Acta - General Subjects , Vol. 1840, pp. 901-905. https://doi.org/10.1016/j.bbagen.2013.04.038

Liang, Y. L., Khoshouei, M., Deganutti, G., Glukhova, A., Koole, C., Peat, T. S., .. Sexton, P. M. (2018). Cryo-EM structure of the active, G s -protein complexed, human CGRP receptor. Nature ,561 (7724), 492-497. https://doi.org/10.1038/s41586-018-0535-y

Liang, Y. L., Khoshouei, M., Glukhova, A., Furness, S. G. B., Zhao, P., Clydesdale, L., .. Wootten, D. (2018). Phase-plate cryo-EM structure of a biased agonistbound human GLP-1 receptor-Gs complex. Nature , 555 (7694), 121-125. https://doi.org/10.1038/nature25773

Mette M. Rosenkilde, Marie Cahir, Ulrik Gether, Siv A. worth, \& Thue W. Schwartz. (1994). Mutations along Transmembrane Segment I1 of the NK-1 Receptor Affect Substance P Competition with Non-peptide Antagonists but Not Substance P Binding. The Journal of Biological Chemst ,269 (45), 28160-28164. Retrieved from https://pubmed.ncbi.nlm.nih.gov/7525569/

Munroe, D. G., Gupta, A. K., Kooshesh, F., Vyas, T. B., Rizkalla, G., Wang, H., .. Steiner, D. F. (1999). Prototypic G protein-coupled receptor for the intestinotrophic factor glucagon-like peptide 2. In Medical Sciences (Vol. 96). Retrieved from https://pubmed.ncbi.nlm.nih.gov/9990065/

Ørskov, C., Hartmann, B., Poulsen, S. S., Thulesen, J., Hare, K. J., \& Holst, J. J. (2005). GLP-2 stimulates colonic growth via KGF, released by subepithelial myofibroblasts with GLP-2 receptors. Regulatory Peptides , 124 (1-3), 105-112. https://doi.org/10.1016/j.regpep.2004.07.009

Parthier, C., Kleinschmidt, M., Neumann, P., Rudolph, R., Manhart, S., Schlenzig, D., .. Stubbs, M. T. (2007). Crystal structure of the incretin-bound extracellular domain of a G protein-coupled receptor.Proceedings of the National Academy of Sciences of the United States of America , 104 (35), 13942-13947. https://doi.org/10.1073/pnas.0706404104 
Parthier, C., Reedtz-Runge, S., Rudolph, R., \& Stubbs, M. T. (2009). Passing the baton in class B GPCRs: peptide hormone activation via helix induction? Trends in Biochemical Sciences , Vol. 34, pp. 303-310. https://doi.org/10.1016/j.tibs.2009.02.004

Pedersen, J., Pedersen, N. B., Brix, S. W., Grunddal, K. V., Rosenkilde, M. M., Hartmann, B., ... Holst, J. J. (2015). The glucagon-like peptide 2 receptor is expressed in enteric neurons and not in the epithelium of the intestine. Peptides , 67 , 20-28. https://doi.org/10.1016/j.peptides.2015.02.007

Qiao, A., Han, S., Li, X., Li, Z., Zhao, P., Dai, A., .. Wu, B. (2020). Structural basis of Gs and Gi recognition by the human glucagon receptor. Nature , 1352 (March), 1346-1352. Retrieved from https://pubmed.ncbi.nlm.nih.gov/32193322/

Richards, P., Parker, H. E., Adriaenssens, A. E., Hodgson, J. M., Cork, S. C., Trapp, S., ... Reimann, F. (2014). Identification and characterization of GLP-1 receptor-expressing cells using a new transgenic mouse model. Diabetes , 63 (4), 1224-1233. https://doi.org/10.2337/db13-1440

Roussel, M., Mathieu, J., \& Dalle, S. (2016, May 1). Molecular mechanisms redirecting the GLP-1 receptor signalling profile in pancreatic $\beta$-cells during type 2 diabetes. Hormone Molecular Biology and Clinical Investigation, Vol. 26, pp. 87-95. https://doi.org/10.1515/hmbci-2015-0071

Sandoval, D. A., \& D'Alessio, D. A. (2015). Physiology of Proglucagon Peptides: Role of Glucagon and GLP1 in Health and Disease.Physiological Reviews , 95 (2), 513-548. https://doi.org/10.1152/physrev.00013.2014

Sasaki, K., Dockerill, S., Adamiak, D. A., Tickle, I. J., \& Blundell, T. (1975). X-ray analysis of glucagon and its relationship to receptor binding. Nature, 257 (5529), 751-757. https://doi.org/10.1038/257751a0

Schiellerup, S. P., Skov-Jeppesen, K., Windelov, J. A., Svane, M. S., Holst, J. J., Hartmann, B., \& Rosenkilde, M. M. (2019). Gut Hormones and Their Effect on Bone Metabolism. Potential Drug Therapies in Future Osteoporosis Treatment. Frontiers in Endocrinology , 10 , 75. https://doi.org/10.3389/fendo.2019.00075

Schirra, J., Sturm, K., Leicht, P., Arnold, R., Göke, B., \& Katschinski, M. (1998). Exendin(9-39)amide is an antagonist of glucagon-like peptide-1(7-36)amide in humans. Journal of Clinical Investigation, 101 (7), 1421-1430. https://doi.org/10.1172/jci1349

Schwartz, T. W., \& Frimurer, T. M. (2017). Structural biology: Full monty of family B GPCRs. Nature Chemical Biology , 13 (8), 819-821. https://doi.org/10.1038/nchembio.2438

Skov-Jeppesen, K., Svane, M. S., Martinussen, C., Gabe, M. B. N., Gasbjerg, L. S., Veedfald, S., ... Hartmann, B. (2019). GLP-2 and GIP exert separate effects on bone turnover: A randomized, placebo-controlled, crossover study in healthy young men. Bone ,125 , 178-185. https://doi.org/10.1016/j.bone.2019.05.014

Song, G., Yang, D., Wang, Y., De Graaf, C., Zhou, Q., Jiang, S., .. Stevens, R. C. (2017). Human GLP1 receptor transmembrane domain structure in complex with allosteric modulators. Nature ,546 (7657), 312-315. https://doi.org/10.1038/nature22378

Sparre-Ulrich, A. H., Gabe, M. N., Gasbjerg, L. S., Christiansen, C. B., Svendsen, B., Hartmann, B., ... Rosenkilde, M. M. (2017). GIP(3-30)NH2 is a potent competitive antagonist of the GIP receptor and effectively inhibits GIP-mediated insulin, glucagon, and somatostatin release. Biochemical Pharmacology , 131 , 78-88. https://doi.org/10.1016/j.bcp.2017.02.012

Sparre-Ulrich, A. H., Hansen, L. S., Svendsen, B., Christensen, M., Knop, F. K., Hartmann, B., ... Rosenkilde, M. M. (2016). Species-specific action of (Pro3)GIP - a full agonist at human GIP receptors, but a partial agonist and competitive antagonist at rat and mouse GIP receptors. British Journal of Pharmacology ,173 (1), 27-38. https://doi.org/10.1111/bph.13323

Sugamura, K., \& Keaney, J. F. (2011). Reactive oxygen species in cardiovascular disease. Free Radical Biology and Medicine, Vol. 51, pp. 978-992. https://doi.org/10.1016/j.freeradbiomed.2011.05.004 
Svendsen, B., Larsen, O., Buur, M., Gabe, N., Christiansen, C. B., Rosenkilde, M. M., ... Holst, J. J. (2018). Insulin Secretion Depends on Intra-islet Glucagon Signaling. Cell Reports ,25 . https://doi.org/10.1016/j.celrep.2018.10.018

Thulesen, J., Knudsen, L. B., Hartmann, B., Hastrup, S., Kissow, H., Jeppesen, P. B., .. Poulsen, S. S. (2002). The truncated metabolite GLP-2 (3-33) interacts with the GLP-2 receptor as a partial agonist. Regulatory Peptides , 103 (1), 9-15. https://doi.org/10.1016/S0167-0115(01)00316-0

Velden, W. J. C. Van Der, Heitman, L. H., \& Rosenkilde, M. M. (2020).Perspective: Implications of Ligand - Receptor Binding Kinetics for Therapeutic Targeting of G Protein-Coupled Receptors . (1). https://doi.org/10.1021/acsptsci.0c00012

Venneti, K. C., \& Hewage, C. M. (2011). Conformational and molecular interaction studies of glucagonlike peptide-2 with its N-terminal extracellular receptor domain. FEBS Letters , 585 (2), 346-352. https://doi.org/10.1016/j.febslet.2010.12.011

Whalen, E. J., Rajagopal, S., \& Lefkowitz, R. J. (2011, March). Therapeutic potential of $\beta$ arrestin- and G protein-biased agonists.Trends in Molecular Medicine , Vol. 17, pp. 126-139. https://doi.org/10.1016/j.molmed.2010.11.004

Willard, F. S., Campbell, J. E., \& Sloop, K. W. (2020). Tirzepatide is an imbalanced and biased dual GIP and GLP-1 receptor agonist .

Wisniewski, K., Sueiras-diaz, J., Jiang, G., Galyean, R., Lu, M., Thompson, D., ... Schteingart, C. D. (2016). Synthesis and Pharmacological Characterization of Novel Glucagon-like Peptide - 2 (GLP-2) Analogues with Low Systemic Clearance . 2 . https://doi.org/10.1021/acs.jmedchem.5b01909

Wu, F., Yang, L., Hang, K., Laursen, M., Wu, L., Han, G. W., ... Stevens, R. C. (2020). Full-length human GLP-1 receptor structure without orthosteric ligands. Nature Communications , 11 (1), 1-10. https://doi.org/10.1038/s41467-020-14934-5

Yamazaki, K., Kagaya, T., Watanabe, M., Terauchi, H., Iida, D., Fukumoto, H., .. Nagakawa, J. (2013). A novel truncated glucagon-like peptide 2 (GLP-2) as a tool for analyzing GLP-2 receptor agonists. Biomedical Research (Tokyo, Japan), 34 (3), 129-136.

Yusta, B., Huang, L., Munroe, D., Wolff, G., Fantaske, R., Sharma, S., .. Drucker, D. J. (2000). Enteroendocrine localization of GLP-2 receptor expression in humans and rodents. Gastroenterology . https://doi.org/10.1053/gast.2000.16489

Yusta, B., Matthews, D., \& Koehler, J. A. (2019). Localization of Glucagon-Like Peptide-2 Receptor Expression in the Mouse.Endocrinology , 160 (8), 1950-1963. https://doi.org/10.1210/en.2019-00398

Zhang, H., Qiao, A., Yang, L., Van Eps, N., Frederiksen, K. S., Yang, D., .. Wu, B. (2018). Structure of the glucagon receptor in complex with a glucagon analogue. Nature , 553 (7686), 106-110. https://doi.org/10.1038/nature25153

Zhang, Y., Sun, B., Feng, D., Hu, H., Chu, M., Qu, Q., ... Skiniotis, G. (2017). Cryo-EM structure of the activated GLP-1 receptor in complex with a G protein. Nature , 546 (7657), 248-253. https://doi.org/10.1038/nature22394

Zhao, L. H., Ma, S., Sutkeviciute, I., Shen, D. D., Edward Zhou, X., De Waal, P. W., .. Zhang, Y. (2019). Structure and dynamics of the active human parathyroid hormone receptor-1. Science, 364 (6436), 148-153. https://doi.org/10.1126/science.aav7942

Zhao, P., Liang, Y. L., Belousoff, M. J., Deganutti, G., Fletcher, M. M., Willard, F. S., ... Wootten, D. (2020). Activation of the GLP-1 receptor by a non-peptidic agonist. Nature , 577 (7790), 432-436. https://doi.org/10.1038/s41586-019-1902-z

TABLE 1 


\begin{tabular}{|c|c|c|c|c|c|}
\hline $\begin{array}{l}\text { Table 1: } \\
\text { cAMP } \\
\text { accumulation }\end{array}$ & $\begin{array}{l}\text { Table 1: } \\
\text { cAMP } \\
\text { accumulation }\end{array}$ & $\begin{array}{l}\text { Table 1: } \\
\text { cAMP } \\
\text { accumulation }\end{array}$ & $\begin{array}{l}\text { Table 1: } \\
\text { cAMP } \\
\text { accumulation }\end{array}$ & $\begin{array}{l}\text { Table 1: } \\
\text { cAMP } \\
\text { accumulation }\end{array}$ & $\begin{array}{l}\text { Table 1: } \\
\text { cAMP } \\
\text { accumulation }\end{array}$ \\
\hline & Ligand & $\begin{array}{l}\text { pEC }_{50}(\mathrm{M}) \pm \\
\text { SEM }\end{array}$ & EC50 $[\mathrm{nM}]$ & $\begin{array}{l}\text { Efficacy } \pm \\
\text { SEM }\end{array}$ & $\mathrm{n}$ \\
\hline \multirow{6}{*}{ hGLP-2R } & hGLP-2(1-33) & $9.7 \pm 0.06$ & 0.22 & $100 \pm 2.5$ & 10 \\
\hline & $\begin{array}{l}\text { hGLP-2(1- } \\
33, \mathrm{M} 10 \mathrm{Y})\end{array}$ & $9.3 \pm 0.06$ & 0.56 & $96 \pm 2.9$ & 4 \\
\hline & hGLP-2(3-33) & $7.6 \pm 0.28$ & 27.5 & $11 \pm 1.5$ & 3 \\
\hline & $\begin{array}{l}\text { hGLP-2(3- } \\
33, \mathrm{M} 10 \mathrm{Y})\end{array}$ & $7.5 \pm 0.32$ & 31.6 & $8.1 \pm 1.2$ & 7 \\
\hline & $\begin{array}{l}\text { hGLP-2 + } 100 \\
\text { nM hGLP-2(3- } \\
33, \text { M10Y })\end{array}$ & $8.9 \pm 0.15$ & 1.4 & $93 \pm 12^{*}$ & 3 \\
\hline & $\begin{array}{l}\text { hGLP-2 }+1 \\
\mu \mathrm{M} \text { hGLP-2(3- } \\
33, \mathrm{M} 10 \mathrm{Y})\end{array}$ & $8.4 \pm 0.20$ & 4.3 & $78 \pm 7.7^{*}$ & 3 \\
\hline \multirow[t]{8}{*}{ hGLP-1R } & hGLP-1 & $11 \pm 0.04$ & 0.03 & $100 \pm 1.3$ & 9 \\
\hline & hGLP-2(1-33) & $7.0 \pm 0.12$ & 98 & $88 \pm 6.0$ & 7 \\
\hline & $\begin{array}{l}\text { hGLP-2(1- } \\
33, \mathrm{M} 10 \mathrm{Y})\end{array}$ & $7.0 \pm 0.13$ & 112 & $100 \pm 8.5$ & 3 \\
\hline & hGLP-2(3-33) & $N . A$. & N.A. & N.A. & 6 \\
\hline & $\begin{array}{l}\text { hGLP-2(3- } \\
33, \mathrm{M} 10 \mathrm{Y})\end{array}$ & $N . A$. & N.A. & N.A. & 6 \\
\hline & $\begin{array}{l}\text { hGLP-2 } \\
+100 \mathrm{nM} \\
\text { exedin }(9-39)\end{array}$ & $6.1 \pm 0.83$ & 881 & $31 \pm 8,9$ & 5 \\
\hline & $\begin{array}{l}\text { hGLP-1 +1 } 1 \mu \mathrm{M} \\
\text { hGLP-2(3- } \\
33, \mathrm{M} 10 \mathrm{Y})\end{array}$ & $10 \pm 0.14$ & 0.07 & $100 \pm 5.5$ & 3 \\
\hline & $\begin{array}{l}\text { hGLP-1 } \\
+100 \mathrm{mM} \\
\text { hGLP-2(3- } \\
33, \mathrm{M} 10 \mathrm{Y})\end{array}$ & $10 \pm 0.22$ & 0.05 & $100 \pm 8.8$ & 3 \\
\hline
\end{tabular}

TABLE 1. cAMP accumulation table values. Signaling values for hGLP-2R and hGLP-1R in response GLP-2 and GLP-2 variants in cAMP accumulation assays. All data were fitted with a three-parameter logistic curve to obtain $\mathrm{pEC}_{50}$. Data represents the mean $\pm \mathrm{SEM}$ of at least three independent experiments performed in duplicates. N.A. refers to no activation detected. ${ }^{*}$ as saturation were not obtained Emax \pm SEM at 10nM hGLP-2(1-33) is given.

TABLE 2

\begin{tabular}{|c|c|c|c|c|c|c|c|}
\hline $\begin{array}{l}\text { Table 2: } \\
\text { Competi- } \\
\text { tion } \\
\text { binding }\end{array}$ & $\begin{array}{l}\text { Table 2: } \\
\text { Competi- } \\
\text { tion } \\
\text { binding }\end{array}$ & $\begin{array}{l}\text { Table 2: } \\
\text { Competi- } \\
\text { tion } \\
\text { binding }\end{array}$ & $\begin{array}{l}\text { Table 2: } \\
\text { Competi- } \\
\text { tion } \\
\text { binding }\end{array}$ & $\begin{array}{l}\text { Table 2: } \\
\text { Competi- } \\
\text { tion } \\
\text { binding }\end{array}$ & $\begin{array}{l}\text { Table 2: } \\
\text { Competi- } \\
\text { tion } \\
\text { binding }\end{array}$ & $\begin{array}{l}\text { Table 2: } \\
\text { Competi- } \\
\text { tion } \\
\text { binding }\end{array}$ & $\begin{array}{l}\text { Table 2: } \\
\text { Competi- } \\
\text { tion } \\
\text { binding }\end{array}$ \\
\hline & & {$\left[{ }^{125} \mathbf{I}\right]-$} & {$\left[{ }^{125} \mathbf{I}\right]-$} & {$\left[{ }^{125} \mathbf{I}\right]-$} & {$\left[{ }^{125} \mathbf{I}\right]-$} & {$\left[{ }^{125} \mathbf{I}\right]-$} & {$\left[{ }^{125} \mathrm{I}\right]-$} \\
\hline & & $\begin{array}{l}\text { hGLP- } \\
2(1- \\
33 . M 10 Y)\end{array}$ & $\begin{array}{l}\text { hGLP- } \\
2(1- \\
33 . M 10 Y)\end{array}$ & $\begin{array}{l}\text { hGLP- } \\
2(1- \\
33 . M 10 Y)\end{array}$ & $\begin{array}{l}\text { hGLP- } \\
2(3- \\
33, \text { M10Y })\end{array}$ & $\begin{array}{l}\text { hGLP- } \\
2(3- \\
33, \text { M10Y })\end{array}$ & $\begin{array}{l}\text { hGLP- } \\
2(3- \\
33, M 10 Y)\end{array}$ \\
\hline
\end{tabular}




\begin{tabular}{|c|c|c|c|c|c|c|c|}
\hline $\begin{array}{l}\text { Table 2: } \\
\text { Competi- } \\
\text { tion } \\
\text { binding }\end{array}$ & $\begin{array}{l}\text { Table 2: } \\
\text { Competi- } \\
\text { tion } \\
\text { binding }\end{array}$ & $\begin{array}{l}\text { Table 2: } \\
\text { Competi- } \\
\text { tion } \\
\text { binding }\end{array}$ & $\begin{array}{l}\text { Table 2: } \\
\text { Competi- } \\
\text { tion } \\
\text { binding }\end{array}$ & $\begin{array}{l}\text { Table 2: } \\
\text { Competi- } \\
\text { tion } \\
\text { binding }\end{array}$ & $\begin{array}{l}\text { Table 2: } \\
\text { Competi- } \\
\text { tion } \\
\text { binding }\end{array}$ & $\begin{array}{l}\text { Table 2: } \\
\text { Competi- } \\
\text { tion } \\
\text { binding }\end{array}$ & $\begin{array}{l}\text { Table 2: } \\
\text { Competi- } \\
\text { tion } \\
\text { binding }\end{array}$ \\
\hline & Ligand & $\begin{array}{l}\mathrm{pEC}_{50}(\mathrm{M}) \\
\pm \mathrm{SEM}\end{array}$ & EC50 [nM] & $\mathrm{n}$ & $\begin{array}{l}\mathrm{pEC}_{50}(\mathrm{M}) \\
\pm \mathrm{SEM}\end{array}$ & EC50 [nM] & $\mathrm{n}$ \\
\hline \multirow[t]{4}{*}{ hGLP-2R } & $\begin{array}{l}\text { hGLP- } \\
2(1-33)\end{array}$ & $7.9 \pm 0.12$ & 14 & 5 & $7.8 \pm 0.09$ & 15 & 5 \\
\hline & $\begin{array}{l}\text { hGLP- } \\
2(1- \\
33, \mathrm{M} 10 \mathrm{Y})\end{array}$ & $7.2 \pm 0.07$ & 59 & 5 & $7.1 \pm 0.13$ & 78 & 6 \\
\hline & $\begin{array}{l}\text { hGLP- } \\
2(3-33)\end{array}$ & $7.2 \pm 0.08$ & 57 & 5 & $7.1 \pm 0.13$ & 81 & 6 \\
\hline & $\begin{array}{l}\text { hGLP- } \\
2(3- \\
33, \mathrm{M} 10 \mathrm{Y})\end{array}$ & $7.3 \pm 0.10$ & 49 & 5 & $7.4 \pm 0.13$ & 41 & 5 \\
\hline mGLP-2R & $\begin{array}{l}\text { hGLP- } \\
2(1-33)\end{array}$ & $8.2 \pm 0.13$ & 6.6 & 3 & $7.7 \pm 0.16$ & 18 & 3 \\
\hline rGLP-2R & $\begin{array}{l}\text { hGLP- } \\
2(1-33)\end{array}$ & $8.3 \pm 0.24$ & 5.4 & 3 & $8.2 \pm 0.18$ & 6.5 & 3 \\
\hline hGLP-1R & $\begin{array}{l}\text { hGLP- } \\
2(1-33)\end{array}$ & $6.9 \pm 0.50$ & 130 & 3 & $6.5 \pm 0.5$ & 330 & 3 \\
\hline mGLP-1R & $\begin{array}{l}\text { hGLP- } \\
2(1-33)\end{array}$ & $6.7 \pm 0.22$ & 208 & 3 & $6.7 \pm 0.14$ & 183 & 3 \\
\hline rGLP-1R & $\begin{array}{l}\text { hGLP- } \\
2(1-33)\end{array}$ & N.B. & N.B. & 3 & $N . B$. & $N . B$. & 3 \\
\hline
\end{tabular}

TABLE 2. Competitive binding values. Binding values $\left[{ }^{125} \mathrm{I}\right]$-hGLP-2(1-33,M10Y) and $\left[{ }^{125} \mathrm{I}\right]$-hGLP2(1-33,M10Y) displaced by increasing concentrations of GLP-2 and GLP-2 variants. All data were fitted with a three-parameter logistic curve to obtain $\mathrm{pIC}_{50}$. Data represents the mean $\pm \mathrm{SEM}$ of at least three independent experiments performed in duplicates. N.B. refers to no binding detected.

\section{FIGURE LEGENDS}

Figure 1. Sequence alignment of GLP-2 and related peptides and activity of hGLP-2 and variants at the hGLP-2R. (a) Alignment of the class B1 GPCR peptides; hGLP-2(1-33), hGIP(1-42), hGCG(1-29), hGLP-1(7-36) (top panel) and the GLP-2 variants; hGLP-2(3-33), hGLP-2(1-33,M10Y) and hGLP-2(3-33,M10Y) (bottom panel). In the top panel, dark grey refers to positions, which are fully conserved (identical), medium grey refers to positions with strongly similar residues, while light grey refers to positions with weakly similar residues. The red box marks position 10 (counted from residue 1 of hGLP-2(1-33)). (b-d) cAMP accumulation dose-response curve for hGLP-2R stimulated with increasing concentration of (b) hGLP-2(1-33) $(n=10)$ and hGLP-2(1-33,M10Y) ( $n=4)$, (c) hGLP-2(3-33) ( $n=3)$ and hGLP-2(3$33, \mathrm{M} 10 \mathrm{Y})(n=7)$, and (d) hGLP-2(1-33) in the presence of $100 \mathrm{mM}$ and $1 \mu \mathrm{M}$ hGLP-2(3-33,M10Y) $(n$ =3). To compensate for inter-assay variations, data have been normalized to hGLP-2(1-33) within each experiment. The experiments were carried out in duplicates and presented as mean \pm SEM.

Figure 2. Homologous competition binding and binding kinetic experiments. (a, b) Homologous binding curve using (a) [ $\left.{ }^{125} \mathrm{I}\right]$-hGLP-2(1-33,M10Y) (black) ( $\left.n=5\right)$ and (b) $\left[{ }^{125} \mathrm{I}\right]$-hGLP-2(3-33,M10Y) (red) $(n=5)$. To compensate for inter-assay variations, the data have been normalized to the specific binding to hGLP-2R within each assay. (c) $\mathrm{B}_{\max }$ for $\left[{ }^{125} \mathrm{I}\right]$-hGLP-2(1-33,M10Y) (black) and [ $\left.{ }^{125} \mathrm{I}\right]$-hGLP-2(3-33,M10Y) (red), normalized to Bmax of [ $\left.{ }^{125} \mathrm{I}\right]$-hGLP-2(1-33,M10Y). (d) Association $(n=4)$ and (e) dissociation $(n$ $=4)$ of $\left[{ }^{125} \mathrm{I}\right]$-hGLP-2(1-33,M10Y) (black) and $\left[{ }^{125} \mathrm{I}\right]$-hGLP-2(3-33,M10Y) (red) on/from hGLP-2R. The 
dissociation was initiated by the addition of $1 \mu \mathrm{M}$ unlabeled hGLP-2(1-33,M10Y) or hGLP-2(3-33,M10Y). (f) Comparison of binding kinetic parameters between $\left[{ }^{125} \mathrm{I}\right]$-hGLP-2(1-33,M10Y) (black) and $\left[{ }^{125} \mathrm{I}\right]$-hGLP-2(3$33, \mathrm{M} 10 \mathrm{Y})$ (red) obtained from association and dissociation assays. To compensate for inter-assay variations data have been normalized for each radioligand within each assay. Differences were analyzed by paired t-test and significance indicated by asterisks, ${ }^{* * * *} \mathrm{p}<0.0001,{ }^{* * *} \mathrm{p}<0.001,{ }^{* *} \mathrm{p}<0.01$ and ${ }^{*} \mathrm{p}<0.05$. ns indicates non-significant differences. The experiments were carried out in duplicated and presented as mean \pm SEM.

Figure 3. Heterologous competition binding using radiolabeled hGLP-2(1-33,M10Y) and hGLP-2(3-33,M10Y). (a) Bar chart of the $\mathrm{pIC}_{50}$ values for binding of $\left.{ }^{125} \mathrm{I}\right]$-hGLP-2(1-33,M10Y) (black) and $\left[{ }^{125} \mathrm{I}\right]$-hGLP-2(3-33,M10Y) (red). (b-e) Competition binding of $\left[{ }^{125} \mathrm{I}\right]$-hGLP-2(1-33,M10Y) (black) and $\left[{ }^{125} \mathrm{I}\right]-$ hGLP-2(3-33,M10Y) (red) displaced by increasing concentrations of (b) hGLP-2(1-33) ( $\left.n=5\right)$, (c) hGLP-2(1-33,M10Y) ( $n=5$ for [ $\left.{ }^{125} I\right]-h G L P-2(1-33, M 10 Y)$ and $n=6$ for $\left.\left[{ }^{125} I\right]-h G L P-2(3-33, M 10 Y)\right),(\mathrm{d})$ hGLP-2(3-33) $\left(n=5\right.$ for $\left.{ }^{125} I\right]-h G L P-2(1-33, M 10 Y)$ and $n=6$ for $\left.\left[{ }^{125} I\right]-h G L P-2(3-33, M 10 Y)\right)$, and (e) hGLP-2(3-33,M10Y) $(n=5)$. To compensate for inter-assay variations the data were normalized to the specific binding of hGLP-2R for each radioligand within each assay. Differences were analyzed by paired t-test and significance indicated by asterisks, ${ }^{* * * *} \mathrm{p}<0.0001,{ }^{* * *} \mathrm{p}<0.001,{ }^{* *} \mathrm{p}<0.01$ and ${ }^{*} \mathrm{p}<0.05$. ns indicates non-significant differences. The experiments were carried out in duplicated and presented as mean \pm SEM.

Figure 4. Test for selectivity among class B1 GPCRs. (a) Phylogenetic tree of the class B1 subfamily GPCRs consisting of the GLP-2R and 14 sequence related GPCRs (modified from (Gasbjerg et al.. 2018)). (b) Heterologous binding of $\left[{ }^{125} \mathrm{I}\right]$-hGLP-2(1-33,M10Y) (black) and [ $\left.{ }^{125} \mathrm{I}\right]$-hGLP-2(3-33,M10Y) (red) to the $\operatorname{hGLP}-1 \mathrm{R}(n=3), \operatorname{hGIPR}(n=2), \operatorname{hGCGR}(n=2), \operatorname{hSecretinR}(n=2), \operatorname{VPAC}-1 \mathrm{R}(n=2)$ and VPAC-2R $(n=2)$ displaced by increased concentrations of endogenous hGLP-2(1-33). The experiments were carried out in duplicated and presented as mean \pm SEM.

See supplementary figure 1 for binding curves.

Figure 5. Binding of the two radioligands to rodent GLP-2Rs and autoradiography . (a, b) Competition binding of [ $\left.{ }^{125} \mathrm{I}\right]$-hGLP-2(1-33,M10Y) (black) and [ $\left.{ }^{125} \mathrm{I}\right]$-hGLP-2(3-33,M10Y) (red) to (a) the $\operatorname{mGLP}-2 \mathrm{R}(n=3)$ and $(\mathrm{b})$ the rGLP-2R $(n=3)$ displaced by increasing concentrations of endogenous hGLP-2(1-33). To compensate for inter-assay variations the data were normalized to the specific binding of respectively mGLP-2R and rGLP-2R for each individual radioligand within each assay. The experiments were carried out in duplicated and presented as mean \pm SEM. Histological sections of the small intestine (c, e) and endocrine pancreas (d, f) after autoradiography in mice injected with (c, d) [ $\left.{ }^{125} \mathrm{I}\right]$-hGLP-2(1-33,M10Y), and (e, f) [ $\left.{ }^{125} \mathrm{I}\right]$-hGLP-2(1-33,M10Y) plus excess amount of unlabeled hGLP-2(1-33,M10Y). The histological sections were counterstained with hematoxylin. Scale bar 50um.

Figure 6. cAMP accumulation mediated by hGLP-2 variants at the hGLP-1R. cAMP accumulation for the hGLP-1R stimulated with increased concentration of hGLP-1 $(n=9)$ and, (a) hGLP-2(1-33) $(n=7)$ and hGLP-2(1-33,M10Y) $(n=3)$, (b) hGLP-2(3-33) $(n=6)$ and hGLP-2(3-33,M10Y) $(n=6)$, (c) hGLP-2(1-33) in the presence of 100nM exendin(9-39) $(n=5)$, and (d) hGLP-1 in the presence of $1 \mu \mathrm{M}$ hGLP-2(3-33,M10Y) and 100nM hGLP-2(3-33,M10Y) $(n=3)$ for the hGLP-1R. To compensate for interassay variations data have been normalized to hGLP-1 within each separate experiment. The experiments were carried out in duplicated and presented as mean \pm SEM.

Supplementary figure 1. Test for selectivity among class B1 GPCRs. (a-f) Competition binding curves of $\left[{ }^{125} \mathrm{I}\right]$-hGLP-2(1-33,M10Y) (black) and [ $\left.{ }^{125} \mathrm{I}\right]$-hGLP-2(3-33,M10Y) (red) to (a) hGLP-1R $(n=3)$ , (b) hGIPR $(n=2),(\mathrm{c})$ hGCGR $(n=2),(\mathrm{d})$ hSecretinR $(n=2),(\mathrm{e}) \operatorname{VPAC}-1 \mathrm{R}(n=2)$, and (f) VPAC-2R $(n=2)$ displaced by increasing concentrations of endogenous hGLP-2(1-33). To compensate for inter-assay variations data have been normalized for each individual radioligand within each assay. The experiments were carried out in duplicated and presented as mean \pm SEM.

Supplementary figure 2. Autoradiography in mice using [125I]-hGLP-2(1-33,M10Y). Histological 
sections of the small intestine (a-f) and pancreatic islet cells (g-l) after autoradiography in mice, injected with $\left[{ }^{125} \mathrm{I}\right]$-hGLP-2(1-33,M10Y) (a-c and g-i) or $\left[{ }^{125} \mathrm{I}\right]$-hGLP-2(1-33,M10Y) plus excess amount of unlabeled hGLP-2(1-33,M10Y) (d-f and j-l). The histological sections were counterstained with hematoxylin. Scale bar $50 \mu \mathrm{m}$.

Supplementary figure 3. Binding of the two hGLP-2 radioligands to rodent GLP-1Rs. (a, b) Competition binding of [ $\left.{ }^{125} \mathrm{I}\right]$-hGLP-2(1-33,M10Y) (black) and [ $\left.{ }^{125} \mathrm{I}\right]$-hGLP-2(3-33,M10Y) (red) to (a) the $\operatorname{mGLP}-1 \mathrm{R}(n=3)$ and (b) the rGLP-1R $(n=3)$ displaced by increasing concentrations of endogenous hGLP-2(1-33). To compensate for inter-assay variations the data were normalized to the specific binding of, respectively, mGLP-1R and rGLP-1R for each individual radioligand. The experiments were carried out in duplicated and presented as mean \pm SEM.

\section{Hosted file}

manuscript figures.docx available at https://authorea.com/users/352361/articles/476666development-of-high-affinity-agonist-and-antagonist-radioligands-for-the-glp-2-receptorpowerful-tools-for-the-study-of-glp-2-pharmacology 